\title{
Character and Non- character in Art Song
}

By

William John Cornish King

An exegesis

submitted to the Victoria University of Wellington in partial fulfilment of the requirements for the degree of Master of Musical Arts

Victoria University of Wellington

2021 


\section{$\underline{\text { Abstract }}$}

Whom is a singer portraying when performing? While this is a straightforward question in opera where there is usually a concrete character to play, it is not always obvious in art song. The persona that the singer portrays in art song is not always clearly delineated: they may be a familiar figure, a nameless wanderer, a detached narrator, or even a disembodied consciousness. The outburst of singing may be an act of soliloquy or an internal thought process. It could occur as part of a chronological sequence of events or perhaps fall outside of time entirely. These portrayals require different embodied instincts from those in operatic singing.

My exegesis explores some of the different kinds of vocal personae one can portray in art song performance. I posit a framework within which I categorise my personal methods of performance, relating to how an audience member might perceive these personae in relation to themselves. With reference to four selected solo vocal works, I detail how my application of this framework informs my performance, resulting in a unique embodiment of these abstract personae. 


\section{Table of Contents}

ACKNOWLEDGEMENTS

SECTION ONE Introduction

i. The Ambiguity of Art Song

ii. Methodology 11

iii. Categorising Perspective: Three Approaches

SECTION TWO: Examination of Selected Works

i. Clérambault's Poliphême: The Omniscient Narrator $\quad 18$

ii. Beethoven's An die ferne Geliebte: The Personality of the Performer 23

iii. $\quad$ Brahms's Vier ernste Gesänge: The Perspective of the Audience 29

iv. Jennings's Thirteen Ways to look at a Blackbird: The Disembodied Instrument 


\section{$\underline{\text { Acknowledgments }}$}

I would like to acknowledge a few people who have helped me complete this thesis.

Firstly, to my academic supervisors Inge van Rij and Hamish Robb. Thank you for your patience with my writing and your ability to translate my babble into coherent thought.

To my teachers, Margaret Medlyn and Wade Kernot. This year was a challenging year to say the least, but taking the time to step back and focus on the craft of singing was such a gift. Thank you for your guidance and the real talk when I needed it.

To my vocal coach David Barnard. Spending twelve months as your "song buddy" has been a joy; I've learned to look at singing in a whole different light and now have a new lease on my artistry.

To my collaborative artists in my recital, Martin Riseley, Samantha McSweeney, and Olivia Wilding. Thank you for your time, talent, and for sharing in my passion for this repertoire.

To the composer of Thirteen Ways of Looking at a Blackbird, Janet Jennings, for giving me permission to perform and analyse her wonderful work.

Finally, to my parents, Denis and Jo King, for always supporting me in this niche and uncertain career path. Without your collective love of music and those hours you spent forcing adolescent me to practise, I never would have discovered the joys of this art form. 


\section{SECTION ONE: INTRODUCTION}

\section{The Ambiguity of Art Song}

Art song is often lauded as a bridge between the instrumental and the operatic. Without the staging, costuming, dramatic lighting and other features of operatic performance, the performer of Lieder is left with the monumental task of moving an audience not by showing a story but by telling a story. However, with the inclusion of spoken language, it is also unlike wordless instrumental music. If we take language to be a means of communication, a point of view or perspective is integral to musical performance that employs language - and this is true in most forms of singing. In opera or dramatic plays, the singer/actor is generally asked to portray a specific character, whereas this character is often obscured in art song or spoken poetry. Moreover, most staged opera contains dialogue, expressed externally by the character in question, which gives clues as to that character's traits. In contrast, art song can vary wildly: it can have a similar narrative pulse and character drive to staged opera, or it may be completely abstract in the sense of who is speaking. It can have this form because it is not necessarily bound by time and narrative constraints. It often portrays an internal monologue that could occur in a single instant; that is to say, outside of time and of the traditional form of narrative. In this way, the performer can make exciting and wildly varying decisions about how they wish to portray the text and music.

This exegesis aims to make sense of the varying perspectives that a singer can portray in art song, and show these in relation to four long-form vocal recital pieces:

\section{Louis-Nicolas Clérambault's Poliphême}

2. Ludwig van Beethoven's An die ferne Geliebte

3. Johannes Brahms's Vier ernste Gesänge

4. Janet Jennings's Thirteen Ways of Looking at a Blackbird.

I will explain my performative process when working with a range of perspectives in art song, and how my understanding of embodiment affects this process. Embodiment for this dissertation's purposes is the manifestation of the artist's musical world and sense of self through the body. It can include how musical sound is produced through the body and how a character or 
perspective can be brought into existence through the body. I will lay out how I came to this understanding in my Methodology below. 


\section{Methodology}

As an undergraduate vocal performance major at Victoria University of Wellington, the primary focus of my study of acting and stagecraft was based on the requirements for operatic performance. However, as is common with young singers, I spent a fair amount of my time analysing and performing art song and have performed several contrasting song cycles. Therefore, in my Masters research, I have worked closely with my coach David Barnard, teachers Margaret Medlyn and Wade Kernot, and supervisors Inge van Rij and Hamish Robb to glean what it is that interests me about art song. Doing so led me to a line of inquiry into the dramatic aspects of the form, as dramatising is such an important step in the process of learning operatic music. I have worked throughout my studies with the Perdekamp Emotional Method, which focuses on the physical sensation of specific emotions and how these in turn inform the body of its processes on stage. ${ }^{1}$ This is particularly useful in an operatic context. However, I have found certain differences in my approach when preparing art song, as there is often a lack of tangible character. While I still examine the emotional content of the songs I perform, I found that when the text was less grounded in narrative and character, I needed to find another focus to extrapolate an additional layer: the question of who is speaking.

I began by researching the concept of embodiment in musical performance. By reading Dr Margaret Medlyn's Embodying Voice: Singing Verdi, Singing Wagner, ${ }^{2}$ as well as Dr Hamish Robb's thesis "Embodying meaning and imagining sound in nineteenth-century piano music", ${ }^{3} \mathrm{I}$ was able to construct a more formalised understanding of how the physical manifestations of performance, in both a technical and dramatic sense, contributed to creating a persona on stage. Medlyn's book came from a vocal technique standpoint, where the physicality of singing is explored, as well as how this physical embodiment of the voices affects an audience. Robb explores the ways that the embodiment of sound manifests in real sounds, bodily movements or states, and what he coins imagined sounds.

\footnotetext{
${ }^{1}$ Perdekamp Emotional Method: PEM Explained (last modified November 23, 2017), https://pem-acting.com/aboutpem/pem-explained.

${ }^{2}$ Margaret Medlyn, Embodying Voice: Singing Verdi, Singing Wagner (London: Routledge, 2018).

${ }^{3}$ Hamish Robb, "Imagined, Supplemental Sound in Nineteenth-Century Piano Music: Towards a Fuller Understanding of Musical Embodiment." Music Theory Online 21/3 (2015).
} 
I used this as a base to explore my own connection to art song, but I soon became fixated on the different suspension of disbelief required on the part of the audience in a recital as opposed to an opera. An audience is not only expected to deconstruct what is being said, but also who is speaking. This concept is discussed in detail in Edward Cone's 1974 book The Composer's Voice. ${ }^{4}$ He explains the concept of the "persona" across art song, opera, and even instrumental music. The all-encompassing term "persona" addresses some technicalities as to whom a singer is when singing, and also what the accompaniment may represent across a myriad of examples. His writing has been influential when preparing my recital and sparked my interest in analysing art song where the question of who is speaking is unclear. Two of the cycles I have programmed do not necessarily have a clear protagonist, and thus it falls to the performer to engage the audience from another angle. As such I have set up a rudimentary framework of three kinds of perspective that one can approach art song with, each of them encompassing how the audience can fruitfully engage with the singer. I have also explored concepts of temporality and narrative in song cycles specifically, and finally discuss the idea of a "collective perspective". Examining the books On Late Style by Edward Said ${ }^{5}$ and Unsung Voices by Carolyn Abbate ${ }^{6}$ has helped me more formally conceptualise what I struggled to process in the past when approaching art song: how to dramatise a persona that lies outside of narrative, time, and character.

A quick disclaimer: The performative process is difficult to formalise in writing. It is different for every performer. There are those who unconsciously express their understanding of the music through their bodies, and those who consciously calculate the best way to communicate their understanding of the music. Both methods are valid, but I generally belong to the former category. The concepts explained in this dissertation are therefore what I glean from the pieces, and how those ideas physically manifest or embody themselves in my own personal performance. They are not prescriptive, and as such are not admonishments on performers who disagree with them. I do hope however that it may stimulate thought on the reader's part, and help to enrich their understanding of art song, as it has done for me.

\footnotetext{
${ }^{4}$ Edward Cone, The Composers Voice, (Berkeley, Los Angeles: University of California Press, 1974).

${ }^{5}$ Edward Said, On Late Style: Music and Literature Against the Grain (London: Bloomsbury Publishing, 2006).

${ }^{6}$ Caroline Abbate, Unsung Voices: Opera and Musical Narrative in the Nineteenth Century (Princeton, New Jersey: Princeton University Press, 1991).
} 


\section{Categorising Perspective: Three Approaches}

One of the most straightforward questions I ask myself when I perform in opera is: why sing? In other words, what is the catalyst that causes me or the character to open their mouth and communicate? This is a relatively simple question to answer in most staged opera, as the narrative usually presents a linear timeline to respond to the action, just as in our everyday lives. However, in art song, one often takes on the role of a narrator, using only spoken commentary to communicate with an audience. Additionally, this information does not always contain narrative and can simply convey a mood or an emotion. A perfect example of this is Robert Schumann's “Mondnacht”, from Liederkreis Op. 39.

\section{It was as though Heaven Had softly kissed the Earth, So that she in a gleam of blossom \\ Had only to dream of him. The breeze passed through the fields, The corn swayed gently to and fro, The forests murmured softly, The night was so clear with stars. And my soul spread Her wings out wide, Flew across the silent land, As though flying home. ${ }^{7}$}

In this poem, it is unclear who is speaking. What is also interesting is that it is also unclear as to why they are speaking, and even more fundamentally, whether they are speaking out loud at all. It does talk of personified versions of heaven and earth, but there is no tangible character that we can latch onto. The song is more like a painting, with music and text invoking a setting, thought, or mood.

This is contrary to most opera, where narration is optional: there is usually a plot, which is conveyed through other means than just the text and music, such as real-time dialogue between characters or visual action. The luxury of staging and of having several singers interact with one another allows for a story to unfold without using a narrator. There are notable exceptions to these rules, such as the narration in the Prologue in Britten's Turn of the Screw, ${ }^{8}$ or the dialogue

\footnotetext{
${ }^{7}$ Joseph Von Eichendorff, "Mondnacht ", Richard Stokes, Oxford Lieder, https://www.oxfordlieder.co.uk/song/542.

${ }^{8}$ Benjamin Britten, The Turn of the Screw, Op. 54, (London, United Kingdom: Boosey and Hawkes, 1966).
} 
between characters in Schubert's Erlkönig ${ }^{9}$ (which incidentally also has a narrator), but for the most part, singers of art song do not always have a concrete character to play. When these staged elements are stripped to the bare minimum in art song, information must be conveyed through other means. The nature of this narration changes depending on what is portrayed and requires a slightly different thought process depending on the text of the poem.

A Glossary of Literary Terms by Abrams sets out a detailed description in its entry of "Point of View" as to the different types of narrator. ${ }^{10}$ The narrator can be presented in several ways including first, second or third person, limited or omniscient perspective, and whether the narrator is impartial to the narrative. This is done through the language used, most obviously in what pronouns are utilised, and how much information is shared. While a firm grasp of this theory is fundamental when it comes to writing narrative, this framework for describing the nature of a narrator is lacking in the case of live performance. The difference between the score and performance is that the performance is embodied, or made manifest physically. While there is not as much visual storytelling as a staged opera, the fact that an art song singer still embodies the works enables another layer of exploration. The singer must consider not only who they are, but who the audience is in relation to them. Therefore, I have constructed a framework to categorise the ways in which the audience is involved with the performance. While this framework is not necessarily designed to be obviously apparent to those observing, it may help the performer compartmentalise who they are in relation to both the music and to their audience.

The question of who is speaking in a poem or a work of fiction is an old question, with even Aristotle creating three categories that roughly correspond to the lyric (speaking in one's own voice), the dramatic (speaking through the voice of characters) and the narrative (combining the two). ${ }^{11}$ Similarly, T.S. Eliot wrote in his 1953 essay "The Three Voices of Poetry" of another trio of perspectives: The poet talking to themselves, addressing the audience, and playing a character. ${ }^{12}$ None of these takes into account the perspective of the audience, however-an

\footnotetext{
${ }^{9}$ Franz Peter Schubert, Erlkönig (version D), D. 328 D / Op. 1, G Minor (Leipzig, Germany: Breitkopf and Härtel, 1897).

${ }^{10}$ M.H. Abrams, and Geoffrey Harpham, A Glossary of Literary Terms (Boston, Massachusetts: Cengage Learning, 2013), 300-305.

${ }^{11}$ Edward Cone, The Composers Voice (Berkeley, Los Angeles: University of California Press, 1974), 1.

${ }^{12}$ T. S Eliot, The Three Voices of Poetry: 2nd ed. (London: Cambridge University Press for the National Book League, 1955).
} 
integral part of the act of performance. Edward Cone further explores in the second chapter of "The Composer's Voice" the idea of the audience being part of the same aural environment as the character in an art song:

"At the same time, this character participates, and is largely formed by, an allencompassing environment of nonverbal sound - an environment to which he in turn contributes through his own melodic line and vocal timbre. And because we as audience are bathed in the same sound, we can feel this environment as ours. To the extent that we do so, we tend to interpret the vocal character in terms of our own sympathies and emotions, and to feel ourselves involved in his. Each of us can thus participate in the sonic environment and hence, to a certain extent, in the nature of the character who comes to live by virtue of that environment."13

I aim to formalise this form of thinking further in order to set up a framework within which I will analyse my four chosen works.

In vocal performance, I believe there are three main focuses of perspective that the singer can draw on. These focuses are not always being in line with traditional literary perspectives, nor with the three perspectives of Aristotle and Eliot. The first and most common is henceforth named Observation Perspective, where the audience observes and empathises with a character created by the performer. The second is Enactment Perspective, where the audience is expected to position themselves in the place of the singer or narrator of the text. It also gently guides them towards the reactions set up by the singer or narrator. In the case of a protagonist of a story, this manifests in being relatively void of distinct character traits, so that the audience can more easily map themselves into their place, while still having an active reaction to the narrative or environment. The third is complete environmental immersion, or the Environmental Perspective. Here, the audience is expected to imagine themselves in a setting created by a sonic space or descriptive text. This is similar to the enactment perspective but instead gives more agency to the audience as to their reaction. While a successful performance often includes combinations of observation, enactment, and environmental perspectives individually or simultaneously,

\footnotetext{
${ }^{13}$ Cone, Composers Voice, 21-22.
} 
distinguishing between the three different focuses of perspective can help better decide how to best aurally communicate with the audience at any given moment.

I posit that conventional narrative-based theatre literature concerns working primarily in the observation perspective. It is the medium that an actor uses to portray a character and draws upon the sympathetic response of an audience to their perspective. While it is not in the focus or scope of this dissertation to extrapolate this much further, it is not without use in the art song literature. As mentioned formerly, Schubert's Erlkönig makes use of several characters who interact with each other, as well as many narrative-based song cycles, notably Robert Schumann's Dichterliebe and Franz Schubert's Die Schöne Müllerin and Winterreise. It also appears to correspond most obviously to Eliot's third perspective of playing a character, but arguably also to the other two: the poet talking to themselves, and to outright addressing the audience.

The enactment perspective involves a persona not to be observed in their own right as an individual character. By removing an extra layer of character comprehension, the text's profundity can, in certain cases, be more directly communicated in both a musical and emotional facility. I have found that the best way to achieve this is to perform the songs with a projection of absolute authority and to avoid mannerisms that would break an audience's immersion. Note that by authority, I am not referring to preaching or lecturing, but rather a confident projection of authority that establishes trust between performer and audience, inviting them willingly to share a particular viewpoint or perspective.

The environmental perspective involves the immersion of the audience member into an aural or imagined environment created by the performers. It differs from the enactment perspective in that there is no imposition of the singer's persona in this perspective, but rather it is for the audience member to react to the environment created. This interactive experience is common in more modern works where the focus of the poetry is no longer on the narrator and their reaction to narrative or concepts, but merely on descriptions of concepts themselves. It is particularly relevant in situations where there is no obvious sense of perspective from the narrator at all. The singer in this instance must give the illusion of a disembodied voice.

While I have presented these perspectives in a chronological order in this exegesis (for the sake of intelligibility), I do not mean to infer that they are evolutions of one another, nor that one is 
more advanced than another. I simply use this order because what I have termed the observation perspective is more commonly talked about in discussions of perspective, and is one I assume will be more familiar to the reader. As such, I will also structure the order of the pieces I am analysing in accordance with this chronology.

When presenting long-form recital music, the perspective of the persona on stage is nuanced and specific to each work. In this exegesis, however, I will grapple with the implications of these differences in four works and will offer brief insights into my interpretation of the score as influenced by these implications. This interpretation of the score embodies itself in my own performance, which I will demonstrate both in my final recital and also in my analysis. 


\section{SECTION TWO: EXAMINATION OF SELECTED WORKS}

\section{Part i: Clérambault's Poliphême: The Omniscient Narrator}

The use of a narrator who is not a specific character in a narrative is not a new phenomenon in song. Folk song for example, often tells a story in strophic form, by way of several verses on the same tune. The singer of these songs takes on the role of a narrator, but also can imitate the voices of the characters in their story. ${ }^{14}$ This kind of persona is utilised similarly in the secular cantata Poliphême by Louis-Nicolas Clérambault. It makes use of both a narrator and also the character of the cyclops Polyphemus. This piece shows the observation perspective quite starkly by specifically embodying a known character from Greek Mythology. His thought process is laid bare in both the arias and the recitatives. It also uses an omniscient narrator, who is used to tell the story outside of direct communication from any of the characters of the story. Through the medium of both body language and vocal colour, the audience should be able to distinguish between the separate personas of the narrator and Poliphême.

The story of the cantata tells a famous tale from Ovid's Metamorphoses. ${ }^{15}$ This tale speaks of the love triangle between Galatea, Acis, and the jealous cyclops Polyphemus, who eventually kills Acis by crushing him with a rock. In the throes of her sorrow, Galatea turns Acis's spirit into a river. However, instead of telling the story from the familiar perspective of the two lovers, it comes from the perspective of Polyphemus. It approaches the stages of his jealousy and emotional journey from despair, to anger, to the violent manifestation of his revenge. This treatment of the text condenses the sentiment of lines 788-872, translated by Rolphe Humphries as "The Song of Polyphemus." 16 It focuses on two main aspects over the first two airs: his sorrow and his anger, linked by his jealousy in the second recitative.

The beginning of the first recitative, the final recitative, and notably the final air, are all from the narrator's perspective, which I find to be an interesting perspective from which to present an air.

\footnotetext{
${ }^{14}$ Richard J Watts and Franz Andres Morrissey, "Voices in the Folk Song," in Language, the Singer and the Song: The Sociolinguistics of Folk Performance, (Cambridge: Cambridge University Press, 2019), 199-225.

${ }^{15}$ Ovid and Rolfe Humphries, Metamorphoses, The New Annotated Edition (Bloomington, Indiana: Indiana University Press, 2018), 330-335.

${ }^{16}$ Ibid., 331.
} 
This is because, in a traditional operatic context, airs or arias are commonly understood to show the thought process of a single character, with the recitative saved for propelling the narrative ahead. The use of this form for a persona who does not participate in the story implies that the narrator may have their own thought process, and it gives clues as to how personable the narrator can be in performance. According to the traditional literary perspectives set out by Abrams, ${ }^{17}$ the narrator in Polipheme speaks in the third person. They also appear to be omniscient; they know the characters' emotions, though primarily focusing on the main character of Polyphemus. However, what makes it striking is the investment the narrator has in the story. The final recitative and aria give the narrator's opinion on the situation, in the form of a moral to learn from the story of Polyphemus's downfall. The portrayal of this sort of narrator walks a fine line between being a character in its own right and being a disembodied retelling of the story's events.

One of the interesting things about the secular cantata — or indeed, the art song — is that since there is no staging, one can play characters that one would never be cast as in an operatic context. Handel's Acis and Galatea has a character of Polyphemus that is sung by a bass; however, since the role is of a giant, the performer's physical appearance must match the expectations set by the role. Ideally, there is a cohesion between the physical appearance of the singer and the sound of their voice. However, the suspension of disbelief in art song and secular cantatas is such that any singer can simply evoke an interpretation of any character's voice. A singer can utilise this to create a distinction between the narrator's voice and the character's voice. On a personal level, my slight stature does not necessarily invoke an expectation of a deep or sonorous voice. Therefore, matching the expectation between the physical and aural elements of my performance give an innate sense of effortlessness and the illusion that I am speaking with my natural and "real" voice. To do this, I think of using my speaking register when singing, a concept in Italian known as "Si canta come si parla". ${ }^{18}$ I do not place as much emphasis on creating as rich or loud a sound as is acoustically possible within my body. This is the timbre I use for a narrator, but on a baser level, it is what I use when I want there to be no dissonance between what the audience sees and what the audience hears. When changing character to the cyclops, making the sound darker, or richer in lower harmonics creates an imbalance between

\footnotetext{
${ }^{17}$ Abrams, and Harpham, A Glossary of Literary Terms, 300-305.

${ }^{18}$ Richard Miller, "Beginning in the Speech-Inflection Range (The Onset)," in Securing Baritone, Bass-Baritone, and Bass Voices (Oxford: Oxford University Press, 2008).
} 
what the audience expects from my physical stature and the sounds they are receiving. They may not perceive that the change of timbre happens on a technical level, but they can hear that it is a different sound from the narrator. It is no longer me as a storyteller, but rather me "putting on a voice”, just like one would in a folk song.

The story begins with the narrator describing the character of Polyphemus, who is in love and jealous. One can present this part of the story with a certain distance by presenting less of the emotional potential in the text, thus establishing oneself as a narrator. I have found one of the simplest ways this manifests in my performance is by avoiding excessive laryngeal tilt during more matter-of-fact narratorial extracts. Laryngeal tilt is a technique that Margaret Medlyn sometimes terms as "cry" or "sob", and as such has a certain emotional 'affect' on an audience. ${ }^{19}$ It is a technique that encourages a thinning of the vocal cords by tilting the larynx. I use it most commonly for high passages, where if one is to maintain the same thickness of vocal cords, it would put too much strain on the voice. ${ }^{20}$ Practically, however, it creates an emotional timbre as implied by its name, and makes it sound like the singer is sobbing or crying. Since the beginning of the recitative is not particularly high in the range for the baritone, keeping the timbre more speech-like ensures that there is a stark difference between the introductory narratorial section, and the entrance of the perspective of Polyphemus later in the recitative. "Venez pas vos appas! Calmez mon trouble affreux!” (“Come through your charms! Calm my terrible trouble!”) With this outcry, which is relatively high in tessitura compared to the opening, sob can be employed. This is under the assumption that one of the main distinguishing factors between a narrator and a character in this context is emotional involvement, something that is readable by an audience through timbre first and foremost. Here I will give a brief description of the vocal process of characterising Polyphemus.

Following the first recitative is the aria lamenting Galatea's preference for Acis. It explores Polyphemus's desire for relief and also showcases his paranoia. This feeling is a rather timeless situation that can be easily embodied in vocal performance by a modern performer. The technique of sob is useful here, especially during the outcries of "Ah" on D4. The paranoia in the

\footnotetext{
${ }^{19}$ Margaret Medlyn, Embodying Voice, Singing Verdi, Singing Wagner (New York: Routledge, 2019), 38; Kimerly Steinhauer, Mary McDonald Klimek, and Jo Estill, The Estill Voice Model: Theory and Translation (Estill Voice International: 2017), 91, 100.

${ }^{20}$ Ibid., 52.
} 
B section, where he fears that Acis is enjoying the company of Galatea, can give way to some "snarl", which is a slight harshening of the voice. When forming a snarling expression with the face, the sound gains higher overtones that an audience aurally perceives as anger or power. This provides an easy transition into the second recitative, which is a turning point in the action: he decides kill Acis. When sob and snarl are used together, it can come across as frustration, which is the perfect colour for "Mais, je l'appelle en vain!" ("But, I call her in vain!") at the beginning of the recitative. The second aria is then characterised by snarl, as it speaks directly of his violent and vengeful thoughts.

The final recitative and aria of the piece are once again from the voice of the storyteller. The beginning of the recitative is a simpler telling of the story, with it ending in "mais, il en est bientôt punis par son amour" ("But he is soon punished by his love.") The story of Polyphemus ends here in the original source material, and shifts to the voice of the poet, or in the practical case of the performance, the singer, giving a moral to the story. This is that jealous lovers should move on rather than seek revenge, as it will cause more pain and suffering. Once again going back to the narratorial perspective, the singer must resume the same colours that they utilised at the beginning of the first recitative. However, the opinionated nature of this narrator gives a little more scope for individual mannerism, as the addition upon the source material appears to imbue the narrator with a moral compass. As such it does not have to be too devoid of emotional involvement.

"En nommant Galatée, Acis quitte le jour," ("Naming Galatea, Acis dies") is a great example of a place where soft tender colours can be utilised to beautiful effect. In fact, the narrator is almost a proxy for the character of Acis in this case, who is a foil to Polyphemus. This is followed by a choice of two approaches to the final two lines of the recitative, of varying emotional involvement of the narrator in the story. The singer can portray the narrator as totally serious, horrified by the murderous actions of Polyphemus. This approach places the narrator directly in the action as if they were simply relaying events as they happened. On the other hand, they can choose to distance themselves from the narrative by stating the text more simply. It is the singer's choice whether to encourage the audience to observe the narrative in real-time or for the moral to be front and centre. 
Following on from establishing the invested narrator, the final aria presents a moral, which is separate from the original story of Ovid's Metamorphoses. The idea of an aria containing a maxim about the story that proceeds it was popular with one of the inventors of the French Secular Cantata, Jean Baptiste Rousseau, who preferred the of structure Italian Cantata. ${ }^{21}$ It is unknown who wrote the text to Poliphême and thus composed the moral, as all but one of Clérambault's cantatas are not attributed to any librettist in published editions. ${ }^{22}$ The narrator in this instance is completely aware of their audience. Therefore, I find it pertinent to vary eye contact with different sections of the audience, as fixating on a single spot implies that the persona is unaware of the audience's presence because they are (in their eyes) presently involved in a narrative.

Poliphême is not a piece that particularly challenges an audience's expectations of persona. The convention of storyteller and character from a single performer is common not only in other cantatas but also of the genre of folk song. Therefore, the pertinence of my framework of observation, enactment, and environmental perspectives was not as relevant to this section, as it almost exclusively deals with the observation perspective. However, what is important is learning how to differentiate between the narrator and the character through the use of tone colour and physical mannerism, so it is always clear to listeners who is speaking. Indeed, this is even more relevant if the audience primarily does not understand French.

\footnotetext{
${ }^{21}$ Donald Herbert Foster, Louis-Nicolas Clérambault and his Cantates Françaises (Ann Arbor, University of Michigan, 1967), 135.

${ }^{22}$ Ibid., 135.
} 


\section{ii. The personality of the individual: Beethoven, An die ferne Geliebte}

An die ferne Geliebte by Ludwig van Beethoven was not only revolutionary in terms of establishing the genre of the song cycle, but also differentiated itself from its precursors in solo vocal chamber music (cantatas) by being ambiguous in terms of narrative and temporality. The entirety of the cycle has almost no narrative impetus. The inner workings of the narrator are the only drama to unfold, which is akin to a fourteen-minute long traditional "aria" of sorts. As such, there are also varying senses of time within the cycle. While the first and final songs are in the present tense and describe the lover's setting and actions, the songs in between simply describe facets of the overall feeling of longing (Sehnsucht). Each song is musically connected to the next, either by piano interlude or by a pedal note in the voice. The final song is a direct quotation of the first song and as such forms a cycle or Kreis. In my performance, I interpret these middle songs not as a progression of different facets of longing, but instead as facets all happening simultaneously. The feelings that the poet Alois Jeitteles was attempting to express are too complex to express with a single poem or indeed a single word, and as such one can perform it with this in mind. In this section, I will address the temporality or lack thereof in the work, and then make sense of the persona within the cycle.

Said's observations about what he terms "late style" imply a certain lack of temporality or timelessness in a composer's late compositions, mainly focusing on Beethoven. He theorised a correlation between the knowledge of a composer's own impending death, and the type of music that they are inclined to produce. ${ }^{23}$ This includes different relationships with time, humanity, or the banally simple, and less focus on heroism and development, especially in the case of Beethoven. An die ferne Geliebte is a composition from the beginning of Beethoven's so-called "late period", where one can infer elements of Said's late style. The poetry of Alois Jetteles acts against our understanding of narrative impulse, and as such, character impulse. There is no development of character through the cycle, nor discrete events that one can react to. Therefore, a singer has the option to approach performing this cycle within the scopes of the observation perspective, but also can play it more from their own perspective than a specific character they have inferred from the source material.

\footnotetext{
${ }^{23}$ Said, On Late Style, 14.
} 
One way that makes sense of poetry that is not from the perspective of an obvious character is to simply portray it from one's own personal perspective. By placing oneself into the events or thought process of the individual, the singer would consequentially produce a unique performance, as each individual has their own way of reacting to the words. There are no right or wrong answers as long as it is personally justifiable, and that the text is expressed organically from the singer's perspective. Beethoven's An die ferne Geliebte is a good example of this, whereby the singer can place themselves in the perspective of the young man parted from his beloved. This way you can show how you as an individual would interpret and react to the words. This is still using a first-person perspective as well as observation perspective, but the defined character is replaced by the singer's own personality.

This is not to say that when portraying a character in an opera, the singer is expected to be completely devoid of their own mannerism or individuality. On the contrary, this is what makes each interpretation of a role so unique. The difference is that in opera, one is usually given far more information about how the character reacts in certain situations. The setting of the opera, the dialogue they have with other characters, the stage directions, the voice type that is used, and in the case of Poliphême, a historical figure that the character is based on, all define the person that the singer embodies. As such there are polarised strong and weak decisions that an artist can make. In art song, however, this information is not always clear. Performers are given more freedom to impose their own perspective onto the music and the text, making the genre an intensely personal experience to perform and to witness.

The first song of Beethoven's cycle is in a basic strophic form for the singer, with only minor changes to the vocal line. It begins by setting up the perspective of the protagonist: where they are and what they are doing. Already, it differentiates itself from the narrator of Poliphême in that the narrator is both part of the world that is being created, and that it is in the present tense. Instead of instructing the audience to imagine the setting, it is as if the audience is privy to the narrator's thought process, and not intended to be witnessing it. "Auf dem Hügel sitz ich spähend in das blaue Nebelland, nach den fernen Triften sehend, wo ich dich, Geliebte, fand." ("I sit on the hill, gazing into the blue expanse of sky, searching the far-off mists to see, where I can find 
you, my beloved." $)^{24}$ This line, notably, is the only line before the final song that sets us in the present in a certain place (on a hill) with a certain action (looking to the sky). I sing this song simply, to establish a blank canvas on which to paint the coming shades of emotion. I also imagine that I have already thought the entire cycle beforehand. It is not as naïve as in "Das Wandern" from Die Schöne Müllerin, in which the narrator does not know the sorrow he is about to experience. Instead, I imagine that the narrator has been on this hill contemplating these thoughts for a long time, and only now is he articulating them into song. The fourth verse of the song articulates the fact he is singing songs, to communicate his pain. This idea of it being a realisation of the narrator's feelings in song rather than a spontaneous thought process implies that it is a rehearsed song. He has already pondered on his emotions and processed them and is now presenting them. Therefore, on the word "Pein" ("pain"), there is a temptation to put lots of cry into the sound, as this evocative word calls for it in isolation. In this case, however, I abstain from excessive emotional outburst as it is not something the narrator is feeling in the moment. Instead, I try to portray a thoughtfulness to the word, that conveys that they have already come to terms with the feeling.

The second song emerges from one of the most beautiful key changes in the art song repertoire, from I root position to III in the second inversion, which invokes warmth. The singer is no longer on the hill of the first song but imagining being in the far-off land where he is gazing at. The mirroring of the change of setting in the relatively distant key change can also add warmth to the tone of the singer. It is as if the song transports the narrator to this spot, where he would like to be. The tied notes seem to hang there like "die Wolke" ("the clouds") do, adding to a sort of weightlessness. In the second verse, the piano takes over the melody, with the singer holding a pedal note on the fifth of the subdominant of the original key. This is important to highlight, as the relationship between singer and pianist is on the surface similar to that of a sonata for solo instrument and pianist, where turns are taken with the main theme and the other part being subdued into the role of accompaniment. It is my belief, however, that the singer is still at the forefront of the texture, not melodically, but textually. Perhaps the piano melody is a lover's manufactured image of their distant beloved, or perhaps it is a memory that is at the forefront of the lover's moment of reminiscence. What is clear is that it is not the literal voice of the lover.

\footnotetext{
${ }^{24}$ Alois Jeittles, "Auf dem Hügel sitz ich spähend”, Carla Maria Verdino-Süllwold, Hampsong Foundation, https://hampsongfoundation.org/resource/ludwig-van-beethoven/\#huegel.
} 
This is interesting because this is contrary to what is often the case in Jennings's Thirteen Ways of Looking at a Blackbird, where the singer takes a more accompanying role as there is no singular character to portray (see section iv).

The third song is very specific in its articulation, with the sung line consisting of short sharp notes with quaver rests in between them. This is in itself an uncommon occurrence in vocal writing, as it can easily disturb what is one of the most important aspects of Bel Canto singing: the legato line. ${ }^{25}$ However, Beethoven uses it to great effect not only to show the breathless excitement of the lover, but also the lightness of approach that is expressed in the text.

Beethoven contrasts this breathlessness with long sweeping legato notes on specific words, usually in places where the text is more expressive than descriptive. It is also specific with its placement of ritardandos; they are usually short, and specifically placed on certain beats of the bar. I find these placed at different times from where I would instinctively pull the tempo; ritardandos tend to happen on the first beats of bars in this genre of music, especially in songs of this tempo. It creates an off-kilter effect, further reinforces the idea that this is a rehearsed cycle of songs on the lover part, but it is interrupted by the contemplations of the lover. They can be played as the interference of dark thoughts in the lover's mind, momentary lapses of concentration in the performance within the performance. In my interpretation, I try to make them look as organic as possible, without an indication that the pianist and the singer are actively trying to coordinate these tempi changes. This is because one can assume that the lover is alone, and he cannot hear a piano in his version of reality.

The long note in the voice linking this last song into "Diese Wolken in den Hohen" "(These clouds on the heights") is easy to see as a mere functional compositional device: a pivot note on the fifth of both the F minor and F major keys of each respective song. The colour must change from tearful to ecstatic, the overriding feeling of this symphonically pastoral fourth song. I do this through a slow decrescendo throughout the note, while maintaining or even increasing the intensity of vibrato. The transition is quite unlike any other in the song repertoire, and having intention behind it means that it is more exciting to listen to. It also reinforces the link between the various facets of the lover's Sehnsucht (longing), and thus also adding to the atemporal

\footnotetext{
${ }^{25}$ Martha Elliott, "Italian Bel Canto", in Singing in Style: A Guide to Vocal Performance Practices (Yale University Press, 2006) 126-59.
} 
nature of the cycle. The excitement of this song gives way to impatience, with the lover demanding the river to flow back to him without delay.

The fifth song is also the final song of the "cycle within the cycle" that the lover presents. It opens with the piano creating its own call and response, a bird-like trill being answered by a faraway horn. This is seemingly indicative of the song, which talks of birds reuniting in the spring. Perhaps it is what the lover hears in the moment, which is what inspires the seemingly improvisatory composition of the song. They almost seem to forget their sorrow, with their personal situation only being highlighted towards the end of the song, with "nur ich kann nicht ziehen von hinnen" (“But I cannot stray from here.”) Finishing the song on this sorrowful note, with "und Tränen sind all ihr Gewinnen" ("And tears are our only reward”) is notable, as it needs to feel like the end of a cycle. All of the lover's desires for these songs to transcend the distance between him and his beloved must be placed into this final section to give a sense of finality to it: that he has finished expressing his longing. Perhaps Beethoven intended that the chord change from the second to the third song rises a major third from C Major to E Major, while the chord change from the fifth to the sixth song falls a major third from A Minor to F Major. In my performance this symbolises the lover rising to sing his performance, and then falling back down into his natural speaking voice. This implies that in this instance, singing is being used as heightened speech.

Although in the final song, the singer claims that what they sing is "was mir aus der vollen Brust, ohne Kunst gepräng' erklungen” (“what comes from their true heart, sprung artlessly”), it is still communication from one person to another, with all the artifices of what this entails with the imperfect medium that is language. It is also ironically only during this and the first song where the lover is not 'performing' in a literal sense, which is truly ohne Kunstgepräng (without artifice). I perform this song in a more relaxed stage manner, both visually and vocally. Finally, when the piano embodies the lover's voice in the final quote of the original theme, it is not the songs he has sung, but the song outside of the song cycle. It is not the art that has transcended the distance, but it is the Sehnsucht itself. This was apparently the goal of the whole cycle, and the motivation for the lover to sing in the first place. The singing was merely a means to that end. The fact that the lover is so nondescript in the cycle makes for a deeply personal performance, similar to Schubert's narrative song cycles. The first and last songs are said to himself, and the 
middle songs are sung to one other person, contrary to the actual singer's situation, which is to perform the cycle to a multitude of people on stage. The personality intrinsic to the individual voice, as well as the stripped-back instrumentation in comparison to an opera means that the audience can more easily believe that indeed they are observing a thought process without artifice. While the suspension of disbelief may need to be greater in terms of the audience being able to see the setting of the story or the costuming of the character, it is also lesser as there is no perceptible conductor or leader of the ensemble. Therefore, the question can be answered readily in the case of my personal performance: it is the singer who is speaking. The only way to maintain this suspension of disbelief however is to hide the cogs in the machine that is the performance; to sing the cycle as the character says, "without artifice". While the audience may imagine themselves in the place of the lover, it primarily deals with the observation perspective, as the audience would still be expected to observe the singer on stage as their own character. When there is no explicit persona, however, it is then an opportunity for greater scope for the audience's perspective can be explored. 


\section{iii. The perspective of the audience: Brahms, Vier ernste Gesänge}

The association between the lower register and voice types with the declamatory and serious goes back to the time of Bach, notably his Passions, where the role of Jesus is played by a Bass. Cox refers to a conceptual metaphor known as Greater is Higher in his assessment of pitch height. Outlined in his book, higher pitch has been correlated to greater, and thus "higher" levels of effort, and as such, heightened emotional intensity. ${ }^{26} \mathrm{He}$ theorises that the reason we have empathetic responses to musical performances is because of our unconscious ability to "subvocalise", or to imagine that we ourselves are singing the notes we hear. When this is applied to instrumental performances, the body must envisage roundabout ways of applying our own vocal mechanism to, for instance, a piano reaching for a high note. While our subvocalisation may be full of effort, a pianist does not have to exert more effort than any other note. As such, they are inclined to mimic the characteristics of "effort" to align the real sound with the subvocalised sound in the audience's vocal mechanism. ${ }^{27}$ They may do this by slightly delaying or increasing the dynamic of the high note.

In the case of the singer, there is not as much distance between the action of the singer and the action of the subvocalisation, as they are, in short, the same mechanism. However, in the case of an opera singer, the production of sound is far different to the average audience member's conception of their own sound production and thus their subvocalisation. This is most manifest in the extremes of voice types, i.e. the high soprano or the low bass. It is the latter that is the more uncommon, and in the Western operatic canon is usually reserved for those of the highest status or those with the most power eg. Wotan, Sarastro, Don Carlo, King Philip etc. I believe there are two main reasons for this relationship between authority and lower voices: the first and most obvious is patriarchal archetypes, but the second, and what I plan to discuss in more detail, is our intrinsic fetishisation of the mind over the body, and our assumption that high notes are a loss of control of our emotions as opposed to low notes being in control.

In our daily lives, we are inclined to "raise" our voices when we are highly emotional, and to "lower" our voices when we are calm. Cartesian dualism, ${ }^{28}$ where the mind is separate from the

\footnotetext{
${ }^{26}$ Arnie Cox, "Pitch Height" in Music and Embodied Cognition. Listening, Moving, Feeling, and Thinking (Indiana: Indiana University Press, 2016), 85-108.

${ }^{27}$ Robb, "Imagined, Supplemental Sound", 4.

${ }^{28}$ The Stanford Encyclopedia of Philosophy, Fall 2020 Edition., s.v. "Dualism."
} 
body, gives rise to our perception of lower voices correlating to lower emotional intensity, and as such to a greater separation between intellect and emotion (which I see as analogous in this situation to mind and body). In other words, we are more likely to take a message delivered at a low pitch as fact, whereas we are more likely to take a message at a high pitch as the fickle whims of one overwhelmed with emotion. This concept is mirrored in public speaking: it is proven that politicians that have lower speaking voices are ranked as more trustworthy than their higher voiced counterparts. ${ }^{29}$ This is, of course, a contentious issue: one far beyond the scope of this exegesis. My application of it, however, is to take advantage of this unconscious bias in order to portray authority, and consequently, the enactment perspective. When performing the declamatory and serious text in Brahms's Vier ernste Gesänge therefore, one must be able to conjure a rich timbre throughout the range that one associates with profundity and depth in order to demand this authority.

Brahms's Vier ernste Gesänge was written at the end of the composer's life, in 1896. Known for its serious meditation on death, it is often compared to Brahms's earlier work, Ein Deutsches Requiem, since it mirrors that work's progression from death to comfort ${ }^{30}$ through texts from the Lutheran Bible. Similarly to the Requiem, the songs do not mention a God figure at any point in the parts of the text chosen from the Bible, which is in line with Brahms's self-proclaimed position as a "humanist." 31 However, Brahms's love of the Bible cannot be dismissed. He interpreted it as a work of literature rather than a religious didacticism, and this had implications for how he chose texts to suit his own musical ends. ${ }^{32}$ Choosing to set religious text has important distinctions for the performance practise of the Vier ernste Gesänge compared to song cycles of a secular nature, as I believe it suggests a different priority of perspective for the audience. In this chapter, I will examine what I believe this to be, and how one can manipulate an audience's preconceptions of authority to create these different perspectives.

The first two songs are from the book of Ecclesiastes, one of the more controversial books of Wisdom from the Old Testament. The book is told from the perspective of an unnamed author,

\footnotetext{
${ }^{29}$ Casey A. Klofstad, Rindy C. Anderson, and Susan Peters, "Sounds Like a Winner: Voice Pitch Influences Perception of Leadership Capacity in Both Men and Women," Proceedings of the Royal Society. B, Biological sciences 279, no. 1738 (2012): 2698-2704.

${ }^{30}$ Michael Musgrave, Brahms, A German Requiem, (Cambridge: Cambridge University Press, 1996) 21.

${ }^{31}$ Ronald Knox, "Brahms and his Religion," Il Saggiatore Musicale 22, no. 2 (2015): 219.

32 Musgrave, Brahms, A German Requiem, 2.
} 
introducing, recounting and reflecting on the teachings of a descendant of David. The crux of the argument is this: The great equalisers are Time and Death; all that we attempt to achieve in life is but "Hevel" - a Jewish word often translated as Meaningless (New International Version) (or "Eitel" in the Luther Bible German, which I have translated as "vanity" (New King James Version). This translation doesn't quite grasp the concept, as the true or more nuanced translation is closer to "vapour" or "breath." 33 Translating it in this way captures the idea that life is difficult to define and that while it may look solid enough to grasp, attempting to categorise it will place it further out of reach (just like trying to grab vapour). At the end of the book, the author concludes that all we can do is fear God and the day of judgement.

Brahms selectively picks lines that do not mention God and chooses to highlight that Man must rejoice in his own pursuits and indeed the simplicity of those works at the end of the first song. However, there is a stark contrast between this book and the first book of Corinthians chapter 13 that makes up the fourth and final song of the cycle. The chapter deals with the idea of love, or in the King James version, charity. ${ }^{34}$ This book is one of the most famous in the Bible, as verses 4-8 (“Love is patient, love is kind...") are often used during wedding ceremonies.

Without the imposition of the music, the chosen texts of Vier ernste Gesänge read to those who do not know the scripture at minimum as an emotionless bible reading, and at most as the musings of a wise teacher. When this profound text is embodied in singing, an historically and inherently personal act, there is a conflict between the music and the text. I believe Brahms bridges this gap by using the middle male voice, a specification unusual for setting an entire cycle. Many famous song cycles in the canon are written for high voice, whether that be tenor or soprano, with the understanding that one can transpose for lower voice types. There is a certain relatability for an audience member, as the baritone is the most common male voice type: extremes of the range are usually not touched upon. ${ }^{35}$ There is also an association with authority due to the richer timbre of the voice type compared to the tenor. The entire cycle spans two octaves, which is also unusual to the genre of Lieder. The lowest parts of the cycle are the slow sections of the first song, and most of the second song, which coincides with the most cynical

\footnotetext{
${ }^{33}$ Russell Meek, "Twentieth- and Twenty-First-Century Readings of Hebel (הֶֶ) in Ecclesiastes", Currents in Biblical Research 14, no. 3 (2016): 279-297.

341 Corinthians 13 (King James Version).

${ }^{35}$ Miller, Securing Baritone, Bass-Baritone, and Bass Voices, 3.
} 
parts of the text "Denn es gehet dem Menschen wie dem Vieh, wie dies stirbt so stirbt er auch," ("It is for Man as it is for beast, as the one dies, so dies the other,") ${ }^{36}$ and "da lobte ich die Toten, die schon gestorben waren" ("I praised the dead which are already dead"). The highest parts of the cycle, in the third and fourth songs, are when the text is at its most human and emotional. "O Tod, wie wohl tust du" (“O Death, how good you feel...") acknowledges one of the elements of time that is most intrinsic to being human: the inevitability of death. The highest point in the cycle, "Nun aber bleibet Glaube, Hoffnung, Liebe, diese drei" ("Now but remains Faith, Hope, Love, these three") reaches the top of the baritone range, a G4.

The projection of an emotional musical line in a high register but with an undercurrent of authority is an opposing diametric of this piece from beginning to end. Notably, the beginning statements of "Denn es gehet dem Menschen wie dem Vieh" show the declamatory, unemotional side of this diametric, with the inevitability of the vocal line being portrayed by it being a literal quotation of the beginning piano motif. The fact that the range of the voice takes over the range of the piano implies that they are in tandem, rather than the voice being an embellishment or afterthought. The tolling of the bell, however, is interrupted by a B flat in the piano, further emphasised by a G\# sharp in the voice, lining up with the first mention of the concept of death, "wie dies stirbt, so stirbt er auch". The text is then repeated, showing the stereotypically emotional part of the music, by climbing to the top of the range. This, however, could also be interpreted to show the power and authority of death as a concept. In performance, I find I must take care with this first instance of the top register, as maintaining authority is key to setting the perspective for the audience. Therefore, I slow the tempo and grow the phrase organically with the rising line, placing firm but not forceful emphasis on the word "stirbt" ("dies") in bar 9. I then maintain this firmness into the cadence into A Major in bar 11 to direct the relatively sparse block chords of the piano part back to the main theme. It is also important to keep movements and facial expressions minimal. Without this approach, an audience would be invited to interpret the singer as having a wild, aggressive reaction to the ominous text, which sets up expectations of observation rather than participation.

\footnotetext{
${ }^{36}$ Richard Stokes, “Vier Ernste Gesänge”, Oxford Lieder, https://www.oxfordlieder.co.uk/song/2296. All translations of this song cycle henceforth are adapted from the same source.
} 
The Allegro section at bar 26 ushers in a change of mood, but not a change of perspective. While the wild accompaniment triplet quavers in the right hand outlining fully diminished chords show an undercurrent of instability, the singer has the option to sit on the front or the back of tempo, which is directly related to what perspective is being portrayed. The interpretation of being on the front of the tempo has a driving quality, which relates more to the observation perspective. However, sitting on the back of the tempo gives more emotional impetus to the whirling piano part and less to the voice. As a result, it makes the voice seem more in control of their emotional faculties, and as such denotes authority, which I believe is more associated with the enactment perspective.

At bar 76, the performer's perspective changes from that of a declamatory statement to the results of their personal thought experiment, shown by the change of pronoun from "es/er" ("they") to "Ich" ("I"), "Darum sahe ich das nicht bessers ist" ("Therefore I perceive that there is nothing better"). Having used the earlier parts of the song to get the audience to inhabit the text/invoke the use of the enactment perspective, the use of the first-person pronoun can now be understood to be referring to the audience themselves. As such we can start using Cox's theories of mimetic response to guide the emotions of the audience not with empathy for me as a narrator, but to feel the emotions within themselves more viscerally, all the while maintaining the undercurrent of authority. The text is a more spontaneous reaction to earlier parts of the song; it is a reaction to the scripture.

"Ich wandte mich und sahe an alle" ("So I returned and considered") creates a more intimate atmosphere by both dynamic, and by vocal range required. The piano introduction has a clarity that the first song does not, in order to introduce a more internal thought process. No longer is there a sense of declamation, but rather of observation. There is almost a godly perspective, as when the text refers to all injustice that happens "unter der Sonne" ("under the sun"), it implies that the narrator is omniscient in the most conspicuous sense. If the performer wishes to avoid moving too far into the observation perspective, they must sing as simply and organically as possible, avoiding extraneous vocal mannerisms such as portamenti or quick dynamic changes. One must also avoid overtly colouring their sound with the colours of the individual words. "Leiden" ("suffer") and "Tränen" (“tears") and "Unrecht" (“oppressions") are not words that apply directly to the narrator, and therefore the perspective that the singer employs must be 
partly removed from those words. As the cycle progresses, the use of "ich" is far more prevalent, which means that if the performer wants to avoid returning to the observation perspective, there are emotions they must avoid arousing from an audience member, most significantly those that are stemmed from sympathetic response towards the singer. The first and most obvious in this set of songs is pity. If the audience feels pity for the narrator of the songs, they are no longer focusing on the text itself, but instead the performer performing them. This sympathetic response distances the audience from the thought process the text lays out, and thus the enactment perspective is diminished. Therefore, it is of utmost importance that there is no diminution in physical stature for this piece.

"O Tod, wie bitter bist du" ("O death, how bitter you are") is the simplest song in the cycle in terms of perspective, as it seemingly addresses a personified death in two different facets: bitterly on behalf of a young man and lovingly on behalf of an old man. In both instances, the perspective is not directly from either of these hypothetical men. It is once again from an outside perspective, and accordingly can be approached as primarily from the second focus of perspective. The singer must therefore remove themselves from initial grief and shock of death; they are simply creating hypothetical situations, or indeed, speaking from past anecdotal experience. This song is most effective when the audience member can apply the message to their own experience, with people they know in place of the young and the old men. This is why it is prudent to remove artfulness for the sake of artfulness in this case and sing ohne Kunstgepräng. The beginning line of the song, quoting Brahms's own Fourth Symphony, consists of two descending lines. This is contrary to the addressing nature of the line, "O death, how bitter you are!" It is almost sheepish; it tails away into the lower register of the voice. The singer is addressing death directly, as in Schubert's Der Tod und das Mädchen. What could be interpreted as anger for the recent loss of a loved one is somewhat softened to an inner thought process, a musing on the nature of death rather than in imperative exclamation of passion. If Brahms had interpreted the text in this way, he may have more precisely quoted his symphony, with the $\mathrm{C}$ natural rising back up the octave, and a slightly more energetic tempo, which again would encourage the observation perspective. Instead, he chooses to use a Grave indication for the tempo and continues the falling thirds down to a $\mathrm{C} 3$, which could be more indicative of imposition upon the audience. Therefore, avoiding too much snarl in the voice or impassioned gesture is pertinent, as doing this would encourage the audience to observe the narrator rather 
than become the narrator. The section "Wenn an dich gedenket ein Mensch" ("When you are thought on by a man"), through the use of diminution quickens the tempo, and includes a relatively pedestrian trochaic rhythm to describe the young man, which is at odds with the rising evocative harmony. It then culminates in an extended falling line all the way from a F\#4 to a B2. Showing some emotional colours in this line can be extremely effective here, as it guides the audience to examine the text in relation to death. "Wenn an dich gedenket ein Mensch, der gute Tage und genug hat und ohne Sorge lebet; und dem es wohl geht in allen Dingen und noch wohl essen mag!" ("When you are thought on by a man that lives good days and is content, and without cares, and that has prosperity in all things; and that is still able to receive food!"). In isolation, this text does not have undertones of tragedy, and it is, therefore, the harmony and the colour of the voice that shows this undercurrent. It then leads back into the initial theme of the song, which can this time be interpreted with more sorrow: perhaps having the context of the young man can induce a memory, which means that it has a less matter-of-fact delivery. Here I utilise more messa di voce in the line to show this sorrowfulness.

The E major section of the song shows the contentment that death grants those who are old and have nothing to live for. The most important part of the delivery of this section is to keep the line going through the many rests. Without it, the rests might be interpreted as a lack of energy, which may show that the singer is impersonating the old man at the end of his life. This does not make sense, because if you are musing on how good death is to those who are old, then you are likely someone who has witnessed someone in pain and then been released. This rejoicing in one's death is not an uncommon concept in the context of religious song. Bach's Ich habe Genug $B W V 82$ shows this in relation to eternal life, with the final movement being a quick dance to show the character's joy. However, one cannot assume that Brahms had this same intention in his song: indeed, he was not a believer himself in this sort of transcendence. It is the joy of release, rather than the joy of heaven that he is referencing in this section. Being as warm as possible in tone colour is therefore pertinent, rather than quietly excited. It is about the sorrow of losing a loved one, yet the happiness in the knowledge they are no longer suffering. This situation is relatable to an audience; many of us have lost loved ones in this situation. Merely opening the door to this emotion for the audience is therefore my intention when performing this section, as anything else is crass and heavy-handed in my opinion. 
"Wenn ich mit Menschen" ("Though I speak with the tongues of men") is famously unlike the other three songs in the cycle. It is decidedly upbeat, and doesn't tackle death quite as overtly: indeed, it is positively simplistic in its final message. However, I believe this final message of "Glaube, Hoffnung, Liebe" ("Belief, Hope, Love") being above all else, is not too dissimilar to the ending of the first song "Darum sahe ich, daß nichts bessers ist, denn daß der Mensch fröhlich sei in seiner Arbeit" ("Therefore I perceive that there is nothing better, than that Man should rejoice in his own works"). All this musing on death is for nothing in the end, and that we should all enjoy our own lives: at the centre of which is belief, hope and above all, love. This relation is what links this song to the rest of the cycle: without it, it seems like it was tacked on by Brahms simply to have an upbeat ending to what were three serious and depressing songs. What is difficult to grapple with in terms of the enactment perspective, however, is that this song is more like a sermon than the others: it preaches rather than muses. It seems less personal, even though it uses personal pronouns liberally.

Here I will state explicitly that using the enactment perspective is not the only way to interpret Vier ernste Gesänge. It is possible to construct a single character that spans the entire cycle, and consequently create a quasi-narrative that justifies the "outburst" of singing that takes place. Indeed, the work of Ecclesiastes is told from a single narrator, and thus can be sympathised within the context of the observation perspective. I believe that having an awareness of the enactment perspective can facilitate a deeper awareness, or a longer-range vision of the music. In practice, there may even be elements of both observation and enactment perspectives in a single performance. 


\section{iv. The disembodied instrument: Janet Jennings, Thirteen Ways of Looking at a Blackbird}

There are certain song cycles where the poetry does not have an explicit narrative or main character. Where this occurs, it becomes more difficult to make sense of portraying the cycle from the singer's individual perspective, as there is not necessarily a sense of a consciousness implied in the poetry. A good example of this is The Songs and Proverbs of William Blake by Benjamin Britten. The poetry is deemed complementary by the composer but there is no explicit consciousness implied by the text, and not necessarily a link between the perspectives of each song. This allows for the performer to open new possibilities that are afforded neither an instrumentalist due to the inclusion of text, nor a traditional opera singer due to the inconsistency of character and lack of tangible narrative. In this sort of music, a performer can choose to portray the text from a non-corporal perspective - perhaps that of an omniscient consciousness or indeed, without consciousness at all. The question then becomes, how does a performer take the inherently embodied practice of singing and create a disembodied perspective? Janet Jennings's Thirteen Ways of Looking at a Blackbird calls for an examination of this practice, and whether it is conducive with this dissertation's previous understandings of a singer's perspective.

Generally, in art song and opera the singer is not expected to directly acknowledge instrumentalists during performance. The thought behind this is that if a singer is completely in the perspective of their character, the music would not be perceptible to the character, or nondiegetic. This is due to two seemingly immiscible concepts in theatrical music, integral to the audience's suspension of disbelief:

1. The singing must be a spontaneous outpouring of emotional and intellectual processes

2. The singing must be a rehearsed, considered, and polished final product

These concepts are alluded to in Cone's "The Composers Voice", in his dichotomy between the verbal (the spontaneous) and vocal (the rehearsed) aspects of the singing persona. He posits that in the case of a character portrayed by a singer: 
"The dramatic circumstances in most cases make it highly inappropriate that he should be aware of his singing...it would destroy the illusion were he to indicate [awareness of the accompaniment] overtly by gesture or facial expression. ${ }^{37}$

It is the "in most cases" part of this quote that interests me. Cone was looking mainly at standard German lieder and operatic music, rather than more contemporary music in his analysis of persona and standard performance conventions. I believe that in the case of Janet Jennings's Thirteen Ways of Looking at a Blackbird, there is a case to be made for more direct communication between singer and instrumentalists, much like an instrumental chamber group. In my analysis of the piece, I will question the notion that total immersion of character is the singular approach of the classical singer. If we are to remove this concept, the audience is free to place themselves into the imaginary aural space created by the musicians, or what I have coined the environmental perspective. This not only adds a more interactive experience for the audience, but also brings the audience's focus away from the singer at key moments in the music. I believe that this strengthens what I believe the composition is trying to communicate: there are many different perspectives of looking at a singular idea or in this case, blackbird, and that context is as important as the object itself.

The use of an additional instrument in art song is not a new concept even in the classical canon. Most notably in this category are Schubert's Der Hirt auf dem Felsen, scored for Soprano, Clarinet and Piano, ${ }^{38}$ and also Brahms's Zwei Gesänge für eine Altstimme mit Bratsche und Pianoforte Op.91. ${ }^{39}$ However, the understanding in common performance practice of these pieces is similar to other lieder: the piano and any other instrument's lines are all part of the singer's consciousness and their world. This is unpacked in detail in Caroline Abbate's book Unsung Voices. ${ }^{40}$ Whether the instruments are a portrayal of a singer's thoughts and emotions, an outside perspective for the singer to react to, or a separate narrative voice altogether, the focus of the audience is generally still directed towards the singer as the carrier of text. Indeed Brahms's Zwei Gesänge has the clue in the title: Two Songs for an alto voice with viola and piano. What differentiates Thirteen Ways of looking at a Blackbird from these entries is the use of relatively

\footnotetext{
${ }^{37}$ Cone, The Composers Voice, 30.

${ }^{38}$ Franz Schubert, "Der Hirt auf dem Felsen,” Leipzig, Germany: Breitkopf and Härtel, 1897).

39 Johannes Brahms, "Zwei gesänge,” (Leipzig, Germany: Breitkopf and Härtel, 1884).

40 Abbate, "Music's Voices" in Unsung Voices.
} 
nonsensical text to invoke a space, with essentially no concrete character so to speak. At times the text of the singer is almost only there to make sense of the musical textures produced by the ensemble as a whole. This is why each individual part of the ensemble informs the others; the traditional model of the singer being the dictator of the musical aspects, and therefore the drama, can be discarded for some parts of the piece. I almost interpret Jennings's comment to "Respond to the 13 stanzas remembering that each is distinct but also part of the whole" as applicable to the instrumentation too: each has a distinct voice, but is also part of a whole.

The beginning of the cycle is eerily slow, with "20 gentles sighs of the bow". It takes over one minute and 20 seconds for the singer to enter. Traditional operatic convention would call for the singer to act as if they are within this sparse texture, which inevitably draws visual focus away from the instrumentalists. Ultimately, this means the audience is fixated on the individual perspective of the singer. However, my interpretation of this stanza is to be more of a commentator and to take a back seat role. I do this by looking at my score or by looking at the violinist. The result is that the audience is directed to focus on the sonic setting created, with the text merely being informed by this setting. "Among twenty snowy mountains" is articulated so slowly, that it is almost incomprehensible. It is difficult to discern a metre without the score in front of you, which gives a weightless feeling in the audience, outside of time and urgency. These physical and sonic cues tell the audience they are there to be immersed in a setting, rather than explicitly told a story.

The second stanza begins with the singer freely declaiming in a recitative style, "I was of three minds, like a tree in which there are three blackbirds". This is punctuated by small interjections by the instruments. The singer informs the speed and feel of the stanza, which is an instance of the singer informing the other instruments of the character. The mezzo forte marking is a stark contrast from the dynamic of the former stanza, which brings the voice out of its supporting role and into the foreground. It also uses a singular personal pronoun, which in itself implies the use of a singular perspective or character to be observed by the audience. However, whether this is communicated to an audience is dependent on whether the singer acknowledges the other instrumentalists. If eye contact is maintained with the audience, we are lead to believe that the interjections are part of the consciousness of the singer. On the other hand, if eye contact is made with the other performers, the singular personal pronoun "I" becomes representative of the three 
performers equally. I believe this is a better approach as this more obviously illustrates the text: the split but still cohesive mind of the unit of three, like three blackbirds in a tree.

The extended introduction to the third stanza introduces a compound time signature, with triplets representing the autumn wind. The violin part falls from the heights playfully, as a representation of the blackbird. Again, the singer seems to come in on top of this texture, merely commenting on what has just occurred in the rest of the ensemble: "The blackbird whirled in the autumn wind". Looking towards other members of the ensemble during their moments shows the scene happening independently, completely outside the singer's control. A lack of physical gesture or vocal mannerism can even put it in the enactment perspective, allowing the audience to be primary observers. It suddenly cuts, however, to the singer alone, for "It was a small part of the pantomime", the perfect opportunity for a glance at the audience, as if to cheekily allude to the genre of the pantomime, and the audience participation that is expected.

The text of stanza four is the most explicit in explaining the collective perspective, with its allusion to three separate entities being one. Before the entrance of the blackbird, there is a certain sensuality to the music, with it being unclear if the Man and Woman being one is sexual innuendo. In bar 113, the peculiarity of the blackbird being involved with the Man and Woman pair is signified by the sudden movement from flowing legato quavers in the piano to a staccato on the word "black". The unison in bars 114 and 115 between the voice, violin, and piano musically illustrates the union between the performers. The common convention is to follow this singer for the timing of the word "one", as the consonant $[\mathrm{w}]$ that proceeds the beat is an easy way to coordinate all performers in changing from the G sharp to the A sharp. It is pertinent to trick the audience into believing that there is no leader in this instance, in order to preserve not only the collective perspective, but also the symbolism in the text. Perhaps the pianist can be intently watching the singer, the violinist intently watching the pianist, and the singer intently watching the violinist. This cyclical setup hides the origin of the cue from the singer to move to the A sharp.

Stanza five once again uses an explicit first-person pronoun, and as such is placed more in the enactment perspective than the environmental perspective. As such, there is a slightly more concrete perspective to play, but it is born of the interplay between the violin and piano. The flirty violin intro opens the question that the perspective poses: do we prefer acts themselves, or 
the implication of those acts? The violin imitates a blackbird's song with a grace note followed by a falling larger interval. One reading would be to to present it playfully, as if the word innuendo is referring to sexual innuendo. My interpretation, however, is to avoid being too expressive, as I believe this persona is only there to guide the audience in their interpretation of the violin's figure. It is also more faithful to what the text is: a question about an observation the persona is making. Assuming the persona is unaware of their audience, they are less likely to overtly "colour" the words for the sake of intelligibility to an audience. Therefore, I prefer to let the words be inspired by what the persona is observing, thereby ensuring that focus is pulled towards the violin.

The sixth stanza uses the environmental perspective, with the violin and piano showing the icicles through ricochet bowing and disjointed figures in the piano. The persona of the singer loses their corporeal form and becomes a narrator, interpreting the aural landscape as a physical one. The meno mosso section in bar 160 employs unison melodic material between the violin and the singer. Here, I make eye contact with the violinist in order to maintain equality between the parts, both of us interpreting the intervallic staccato jumps in bar 162 as representative of the blackbird's shadow moving on the window.

Stanza seven contains slightly more musically comedic material; in bar 187 the singer appears to "plod" to emulate the walking blackbird. The use of duplets in bar 189 against the established compound metre emphasises this, as blackbirds are bipedal. The singer addresses the audience as if they were the "thin men of Haddam", asking them a rhetorical question. The piano is not emulating our preconceived notions of melodic singing but rather the other way round: the staccato marking in both the voice and the piano is more percussive than melodic. This could mean that the blackbird walking is represented by the piano, with the singer's line being commentary and thus utilising the environmental perspective.

Jennings interprets "noble accents" and "lucid, inescapable rhythms" as a chaconne, a slow baroque dance that emphasises the second beat of a triple metre. The singer makes heavy use of the pronoun "I" which leans towards the enactment perspective. However, the lengthy violin instrumental introduction means the audience can interpret that the singer's entry is a reaction to it, and thus not the singer's own "original" material. You can therefore also place it in the 
environmental perspective, with the singer merely describing the musical material that has preceded their entry. Therefore, I look at the violinist intently during the beginning of this stanza. Stanza nine is similar to the previous stanza in that it again comments on the musical material from the piano and violin. However, what makes it unique is that the instruments are tacet during the vocal lines, while the singer is tacet during the instrumental lines. This separation makes the reaction and commentary aspect of the stanza more obvious, and gives space for the audience to hear the text and use its content to inform them of what the instruments are representing. In this case, it appears to represent the path of a flighty blackbird. However, the slightly ominous harmonic movement in bar 247 shows the singer is once again introducing their own material, and as such is more informed by the enactment perspective in my performance. This is because it is now imposing on the audience an unobvious interpretation of the texture, and as such can be faced out to the audience.

Stanza ten, marked energico by Jennings, utilises harsh textures that simulate a flurry of blackbirds, the visual spectacle of which causes even the bawds (which once meant a woman in charge of a brothel) of euphony to descend into cacophony. The physicality that accompanies the rhythmic impetus of this stanza is particularly difficult to separate from the illusion of a disembodied narrator. Therefore my instinct is to lean into this impetus, by connecting completely and utterly with the other members of the ensemble, tapping into their embodied performances and using this to inspire my own physical and vocal delivery. I find it difficult to stand still in this section, opting rather to "groove" along, which alludes to the aforementioned collective perspective where the entire ensemble acts as a single perspective. When the physicality of all the musicians is aligned, I see the group as a collective organism rather than the singer being separated, not unlike an instrumental ensemble in more traditional chamber music.

The eleventh stanza incorporates rolling ostinato in the piano, along with folky fiddle-esque tunes in the violin. It makes heavy use of offbeat rhythms, possibly as a reference to the previous stanza's violin rhythms, but in a much less sinister way. The infectious rhythm informs my body with toe-tapping and instinctive body movements to show the instrument-led texture where the singer is merely along for the ride.

Where stanzas ten and eleven were marked by rhythmic impetus, stanza twelve returns to a more ethereal soundscape. What makes it different is that there is a clear linear thought process: "The 
river is moving, the blackbird must be flying." If $\mathrm{A}$ is true, then B must be true. Therefore I believe this falls into the enactment perspective, imposing the causation between the river and the blackbird upon the audience rather than telling it. This physically manifests in my performance as a more simplistic physical stance: simply looking out at the audience.

The final stanza returns to the material of the first stanza, following a formula utilised by Beethoven's An die ferne Geliebte, wherein the cyclicity is emphasised by musically linking the beginning and end. The text of this stanza is particularly atemporal, "It was evening all afternoon. It was snowing and it was going to snow." I find being as still as possible when performing this section is important, as any sudden movements can pull the audience out of this timeless ethereal texture. It is difficult to discern metre, but the text is generally said a bit faster than the first stanza, making it more intelligible.

When I have sung modern works like Jennings's Thirteen Ways of looking at a Blackbird in the past, I have always had difficulty in cohesively creating a character across the work in the same way I would in a more character- or narrative-based work. However, having an awareness of the different perspectives, both from the singer's point of view and the audience's point of view, ultimately guided me to the conclusion that another approach was possible: that of the enactment and environmental perspectives. Being able to formalise my instinctive reaction to the music helped me to justify my embodiment of the music, and also helps me to explain that form of embodiment to audience members and other performers. 


\section{SECTION THREE: CONCLUSION AND MOVING FORWARD}

In terms of the perspectives that fall outside the three outlined in this exegesis, the framework I have presented here could potentially be expanded further if there is a kind of persona that can be interpreted differently again. This may be relevant in other genres of music as well, including more modern opera, other works of vocal chamber music, and oratorio. It could even be expanded to be applicable to contemporary styles of vocal music, such as jazz or pop music. It might hold potential as a useful framework in the world of instrumental music, albeit in a more abstract way, as there is no inclusion of text, nor necessarily an expectation from the audience that the instrumentalist is playing a persona. In this case, the framework might need to be more dependent on a close relationship with other parameters that could help shape a sense of persona or narrative: motif, form, tone colour, and a performer's physical style of presentation.

There could also be applicable research into how these three perspectives can be adapted into easily digestible concepts as an aid for teachers. Focusing on the perspective of the audience may be a helpful tool for less experienced singers to conceptualise their performance outside of themselves, and to help with taming their inner critic. In terms of my personal development, what has been enlightening in the process of writing about this framework is applying it to repertoire outside of what was presented in my recital. As previously mentioned, oratorio work, in particular, has a great potential for analysis and discussion: perhaps not in the un-staged biblical stories of Handel but certainly in the Messiah, or Bach's Passions, or even Masses and Requiems. However, in saying this, I am by no means suggesting that these techniques are exhaustive of all un-staged singing. While it has a wide application to performative processes, largely those found in nineteenth-century German lieder, it is beyond the scope of this exegesis to encompass a wider range of possibilities than the current offering.

The performance of art song is shrouded in tradition and largely unspoken ritual. My conceptualisation of the collective perspective, while partly in aid of facilitating a deeper awareness of the music, is also to challenge these traditions and rituals and stimulate conversations between collaborators. This is admittedly where the idea for the collective perspective came from: a questioning of the status quo, and of assumptions made by both singers and instrumentalists in collaborative projects I have personally been involved in. Rather than relegating instruments to accompaniment and singer to the storyteller, more options can be 
explored in terms of the physicality of the chamber group. Not only does this lessen the divide between collaborators, but this may in fact instil a sense of satisfaction in those observing the performance: live collaboration is exciting to watch. This is not to say that there is no place for the separation of singers and instrumentalists, but instead that the options can be broadened, and conversations initiated.

So, whom is a singer portraying when performing? Formalising my framework of the three perspectives has enabled me to answer this question in relation to each of my case studies, and also has given me the tools to apply them to other vocal pieces of music. I have been able to observe my own growth as a performer of art song, and indeed of all kinds of vocal music. The question of who is speaking is not a new one: Edward Cone's influential The Composer's Voice was published decades ago and has been an integral part of the musicological scholarship ever since. Reading this book changed how I view performers and made me question what I am seeing as an audience member. It made me aware of when a singer was purposefully creating a persona, and when they were conspicuously themselves as a performer.

However, applying this knowledge to my own performance was a completely new experience. My interpretation of the music was often changed when I was no longer viewing myself only as a character to be empathised with, but potentially as a proxy for the audience's perspective. It also justified some of the things I was already doing instinctively, and what many singers may do themselves. This begs the question: do I believe knowledge of these perspectives to be integral to presenting art song? While I believe it enriches my own performance, it may be the case that it does not work for other singers. I imagine that many singers may perform in similar ways instinctively or may rationalise these instincts with altogether different concepts of their personas. What I do hope is that by providing a framework through which a singer can more readily articulate who they are in various pieces of art song, it may inform that singer's embodiment, and thus enhance their ability to communicate with their audience. 


\section{Bibliography}

Abbate, Caroline. Unsung Voices: Opera and Musical Narrative in the Nineteenth Century. Princeton, New Jersey: Princeton University Press, 1991.

Abrams, M.H., and Harpham, Geoffrey. A Glossary of Literary Terms. Boston, Massachusetts: Cengage Learning, 2013.

Brahms, Johannes. Zwei gesänge. S.l: Breitkopf and Härtel, 1884

Cone, Edward. The Composers Voice. Berkeley, Los Angeles: University of California Press, 1974.

Casey A. Klofstad, Rindy C. Anderson, and Susan Peters. Sounds Like a Winner: Voice Pitch Influences Perception of Leadership Capacity in Both Men and Women." Proceedings of the Royal Society. B, Biological Sciences 279, no. 1738 (2012): 2698-2704.

Bean, Matt. 'Gesture in art song and opera'. Journal of Singing - the Official Journal of the National Association of Teachers of Singing 54/5 (1998), 37-39.

Coessens, Kathleen. "On the Sensorial of the Human Body in Performance". In Sensorial Aesthetics in Music Practices. Leuven: Leuven University Press, 2019. 133-150.

Cox, Arnie. Music and Embodied Cognition: Listening, Moving, Feeling, and Thinking. Bloomington; Indianapolis: Indiana University Press, 2019.

Eichendorff, Joseph Von. "Mondnacht", Richard Stokes. Oxford Lieder. https://www.oxfordlieder.co.uk/song/542.

Eliot, T. S. The Three Voices of Poetry: 2nd ed. London: Cambridge University Press for the National Book League, 1955.

Elliott, Martha. Singing in Style: A Guide to Vocal Performance Practices. New Haven: Yale University Press, 2006.

Foster, Donald Herbert. Louis-Nicolas Clérambault and his Cantates Françaises. Ann Arbor: University of Michigan, 1967.

Heisel, Erin. 'Empathy as a Tool for Embodiment Processes in Vocal Performance'. Empirical Musicology Review, 10/1 and 2 (2015), 104-110.

Jeittles, Alois. "Auf dem Hügel sitz ich spähend”, Carla Maria Verdino-Süllwold. Hampsong Foundation. https://hampsongfoundation.org/resource/ludwig-van-beethoven/\#huegel.

Laws, Catherine. "Embodiment and Gesture in Performance Practice-led Perspectives." In Artistic Experimentation in Music, ed. Darla Crispin and Bob Gilmore. Leuven: Leuven University Press, 2014. 
Medlyn, Margaret. Embodying Voice: Singing Verdi, Singing Wagner. New York: Routledge, 2019.

Miller, Richard. Securing Baritone, Bass-Baritone, and Bass Voices. Oxford: Oxford University Press, 2008.

Musgrave, Michael. Brahms: A German Requiem. Cambridge: Cambridge University Press, 1996.

Östersjö, Stefan. 'Thinking-through-Music On Knowledge Production, Materiality, Embodiment, and Subjectivity in Artistic Research'. In Artistic Research in Music: Discipline and Resistance, ed. Jonathan Impett. Leuven: Leuven University Press, 2017. 88-107.

Ovid, and Rolfe Humphries, Metamorphoses, The New Annotated Edition. Bloomington, Indiana: Indiana University Press, 2018.

Perdekamp Emotional Method: PEM Explained. Updated November 23, 2017. https://pemacting.com/about-pem/pem-explained.

Robb, Hamish. 'Imagined, Supplemental Sound in Nineteenth-Century Piano Music: Towards a Fuller Understanding of Musical Embodiment'. Society for Music Theory 21/3 (2015).

Robinson, Howard, "Dualism", The Stanford Encyclopedia of Philosophy (Fall 2020 Edition), Edward N. Zalta (ed.), URL $=<$ https://plato.stanford.edu/archives/fall2020/entries/dualism/>.

Schneider, Rebecca. 'In Response, a Call'. Cambridge Opera Journal 16/3 (2004), 307-309.

Schubert, Franz. Der Hirt auf dem Felsen. S.1: Breitkopf and Härtel, 1897.

Schubert, Franz Peter. Erlkönig (version D), D. 328 D/Op. 1, G Minor .Leipzig, Germany: Breitkopf and Härtel, 1897.

Stokes, Richard. "Vier Ernste Gesänge". Oxford Lieder.

https://www.oxfordlieder.co.uk/song/2296.

Watts, Richard J., and Franz Andres Morrissey. Language, the Singer and the Song: The Sociolinguistics of Folk Performance. Cambridge: Cambridge University Press. 2019 